\title{
Resistance to Plum Pox Virus (Dideron Isolate RB3.30) in a Group of California Almonds and Transfer of Resistance to Peach
}

\author{
P. Martínez-Gómez, M. Rubio, and F. Dicenta \\ Departamento de Mejora y Patología Vegetal, Centro de Edafología y Biología Aplicada del Segura- \\ Consejo Superior de Investigaciones Científicas, P.O. Box 4195, E-30080 Murcia, Spain
}

T.M. Gradziel1

Department of Pomology, University of California, One Shields Avenue, Davis, CA 95616

AdDitional InDEX woRds. Prunus dulcis, Prunus persica, sharka, interspecific hybridization, germplasm, ELISA-DASI, RT-PCR

\begin{abstract}
Sharka [(plum pox virus (PPV)] mainly affects Prunus species, including apricot (Prunus armeniaca L.), peach (Prunus persica L.), plum (Prunus salicina Lindl., Prunus domestica L.), and, to a lesser degree, sweet (Prunus avium L.) and sour cherry (Prunus cerasus L.). Level of resistance to a Dideron isolate of PPV in seven California almond $[P$. dulcis (Miller) D.A. Webb], five processing peach cultivars, and two peach rootstocks was evaluated. In addition, almond and peach selections resulting from interspecific almond $x$ peach hybridization and subsequent gene introgression were tested. Evaluations were conducted in controlled facilities after grafting the test genotypes onto inoculated GF305 peach rootstocks. Leaves were evaluated for PPV symptoms during three consecutive cycles of growth. ELISA-DASI and RT-PCR analysis were also employed to verify the presence or absence of PPV. Peach cultivars and rootstocks showed sharka symptoms and were ELISA-DASI or RT-PCR positive for some growth cycles, indicating their susceptibility to PPV. Almond cultivars and almond $x$ peach hybrids did not show symptoms and were ELISA-DASI and RT-PCR negative, demonstrating resistance to PPV. Two (almond $x$ peach) $F_{2}$ selections as well as two of three backcrossed peach selections also showed a resistant behavior against the PPV-D isolate. Results demonstrate a high level of resistance in almond and indicate potential for PPV resistance transfer to commercial peach cultivars.
\end{abstract}

Sharka, as caused by plum pox virus (PPV), is a serious disease of temperate fruit production. PPV affects most Prunus species, resulting in severe economic losses in apricot (Prunus armeniaca), plum (Prunus salicina, Prunus domestica), and peach (Prunus persica) (Németh, 1994). PPV has also recently been detected in sweet cherry (Prunus avium) (Creszenci et al., 1997). Described for the first time in Bulgaria in 1917, sharka spread throughout Europe, North Africa, India, and Chile (Németh, 1994), and more recently to North America (Levy et al., 2000). PPV is characterized by a high genetic variability. Two major strains, Dideron (PPV-D) and Marcus (PPV-M), exist in Western Europe (Candresse et al., 1994). Other less common PPV isolates include El Amar (PPV-E) in North Africa and Cherry (PPV-C) in Central Europe (Kölber, 2001). To date, only PPV-D isolates have been detected in North (United States and Canada) (Damsteegt et al., 2001) and South America (Chile) (Reyes et al., 2001).

Because of its rapid transmission by aphids, sharka is difficult to control (Németh, 1994). Short-term field control methods include the removal of diseased trees and planting certified virus-free material. The development and cultivation of resistant cultivars, however, may be the only long-term solution. The development of resistant genotypes and the associated search for sources of resistance to sharka are the two of most important objectives of Prunus improvement programs in Europe, including apricot (Audergon et al., 1994; Egea et al., 1999), plum and prune (Dosba et al., 1994; Kegler et al., 1994), and peach (Gabova, 1994; Pascal et al., 2003).

Received for publication 13 June 2003. Accepted for publication 11 Dec. 2003. We gratefully acknowledge the assistance of Mariano Gambín in experimental work. This study was supported by funds from the Almond Board of California, California Association of Nurserymen, and the California Cling Peach Advisory Board.

${ }^{1}$ Corresponding author; e-mail tmgradziel@ucdavis.edu.
Peach and almond [P. dulcis (Miller) D.A. Webb syn. P. amygdalus Batsch] represent consanguineous species that evolved under two distinct environments, being warmer and more humid in the case of peach, and colder and xerophytic for almond (Watkins, 1976). Gradziel et al. (2001) and Gradziel (2003) have previously demonstrated the use of almond germplasm for peach improvement. No source of PPV resistance has been described in P. persica to date (Escalettes et al., 1998; Gabova, 1994; Pascal et al., 2003), although almond has been described as a nonhost species (Németh, 1994; Kölber, 2001). Resistance to PPV in some almond cultivars has been described (Dicenta et al., 2002; Pascal et al., 2003; Rubio et al., 2003). Pribék et al. (2001), however, previously described the presence of a Type Dideron isolate infecting almond plants, and Dallot et al. (1997) also reported experimentally infecting the 'Aï' almond cultivar by graft-inoculation.

In this study, PPV-D resistance for several Californian almond and peach cultivars, interspecific almond $\mathrm{x}$ peach hybrids and selfed and backcrossed progeny was evaluated under controlled conditions using both visible leaf symptoms as well as molecular probes for disease identification.

\section{Materials and Methods}

Plant materials. Plant material evaluated included seven almond cultivars, five processing peach cultivars, and two peach rootstocks (Table 1). Also tested were genotypes resulting from interspecific almond $x$ peach hybridization as well as subsequent backcrossing and selfing with selection for peach fruit types.

PPV ISOLATE. PPV isolate RB3.30 was used as virus inoculum and is a Dideron Type isolate obtained in Spain from the plum 'Red Beaut'. The isolate is maintained at the Instituto Valenciano de Investigaciones Agrarias (IVIA) Valencia, Spain (Asensio, 1996). 
Table 1. Plant material evaluated including the origin, use, and main horticultural characteristics; $\mathrm{BC}=$ backcrossed.

\begin{tabular}{|c|c|c|c|c|c|c|}
\hline \multirow[b]{2}{*}{ Genotype } & \multirow[b]{2}{*}{ Origin } & \multirow[b]{2}{*}{ Use } & \multicolumn{4}{|c|}{ Horticultural characteristic } \\
\hline & & & Endocarp & $\begin{array}{l}\text { Mesocarp } \\
\text { color }\end{array}$ & $\begin{array}{l}\text { Mesocarp } \\
\text { texture }\end{array}$ & $\begin{array}{l}\text { Flowering } \\
\text { time }\end{array}$ \\
\hline Carmel & Nonpareil x Mission & Almond & Paper & White & Almond-like & Very early \\
\hline Mission & Early California selection & Almond & Hard & White & Almond-like & Early \\
\hline Ne Plus Ultra & Early California selection & Almond & Soft & White & Almond-like & Very early \\
\hline Nonpareil & Early California selection & Almond & Paper & White & Almond-like & Early \\
\hline Padre & Mission x Swanson & Almond & Hard & White & Almond-like & Early \\
\hline Price & Nonpareil x Mission & Almond & Paper & White & Almond-like & Early \\
\hline Sonora & Nonpareil x Eureka (BC) & Almond & Paper & White & Almond-like & Very early \\
\hline Andross & Early California selection & Processing peach & Hard & Yellow & Peach-like & Late \\
\hline Bolinha & Brazilian selection & Processing peach & Very hard & Yellow & Peach-like & Early \\
\hline Dr Davis & California selection & Processing peach & Hard & Yellow & Peach-like & Late \\
\hline Halford & Lovell seedling & Processing peach & Very hard & Yellow & Peach-like & Late \\
\hline Ross & California selection & Processing peach & Very hard & Yellow & Peach-like & Late \\
\hline Lovell & Early California selection & Peach rootstock & Very hard & White & Peach-like & Late \\
\hline Nemaguard & P. davidiana $\mathrm{X}$ peach & Peach rootstock & Very hard & White & Intermediate & Early \\
\hline Hansen 536 & Almond $x$ peach & Hybrid rootstock & Very hard & White & Intermediate & Very early \\
\hline Nickels & Almond $x$ Nemaguard & Hybrid rootstock & Very hard & White & Intermediate & Early \\
\hline $54 \mathrm{P} 455$ & Peach selection & Peach breeding line & Hard & Yellow & Peach-like & Early \\
\hline $7926-1$ & Padre almond $\times 54 \mathrm{P} 455$ & Hybrid breeding line & Very hard & White & Intermediate & Early \\
\hline F10C,20-51 & $($ Padre $\times 54 \mathrm{P} 455) \mathrm{F}_{2}$ & Almond breeding line & Paper & White & Peach-like & Early \\
\hline F10C, $12-28$ & $($ Padre $\times 54 \mathrm{P} 455) \mathrm{F}_{2}$ & Almond breeding line & Paper & White & Peach-like & Early \\
\hline $\mathrm{F} 8,5-156$ & $($ Peach $\times$ F10C, $12-28) \mathrm{F}_{2}$ & Peach breeding line & Very hard & Yellow & Peach-like & Early \\
\hline F8,5-166 & $\left(\right.$ Peach $\times$ F10C, 12-28) $\mathrm{F}_{2}$ & Peach breeding line & Very hard & Yellow & Peach-like & Early \\
\hline $99,15-154$ & (Peach $x$ Nonpareil) $\mathrm{BC}_{2}$ & Peach breeding line & Very hard & Yellow & Peach-like & Late \\
\hline
\end{tabular}

RESISTANCE EVALUATION PROCEDURE. Evaluation experiments were carried out in a sealed greenhouse in Murcia (Spain), following procedure described by Martínez-Gómez and Dicenta (1999). Scions were propagated onto infected symptomatic GF305 peach seedlings (one scion per seedling). GF305 peach is characterized by its susceptibility to PPV (Bernhard et al., 1969). Following 4 months of growth, scion-grafted trees were forced into dormancy by subjecting them to $7{ }^{\circ} \mathrm{C}$ and darkness for 2 months. After this cold dark treatment, trees were moved to an insect-proof greenhouse for 4 months. Three cycles of evaluation were performed over 2 years. The number of plants evaluated depended on scion graft success as only plants where the GF305 rootstock showed unambiguous PPV symptoms were considered as successfully inoculated. During each growth cycle leaf symptoms were scored from 0 (no symptoms) to 5 (maximum intensity of symptoms as observed on GF305 rootstock) at 2 months following budbreak. PPV symptoms evaluated include chlorotic discoloration of expanding and mature leaves and deformations of leaf tips and margins (Fig. 1). ELISA-DASI or RT-PCR positive reactions and the presence of disease symptoms in leaves in any cycle indicated the susceptibility of the genotype.

ELISA-DASI ANALYSIS. To ascertain the presence or absence of PPV in samples, an ELISA-DASI (Double Antibody Sandwich Indirect) assay was applied to the leaves during the first and third growth cycles using the $5 \mathrm{~B}$ monoclonal antibody against the coat protein of PPV (Cambra et al., 1994). Optical densities (OD) at $405 \mathrm{~nm}$ were recorded after $60 \mathrm{~min}$. In accordance with Sutula et

Fig. 1. Disease response following grafting onto PPV infected rootstock. (A) Absence of PPV symptoms in Nonpareil almond grafted onto GF305 showing strong symptoms of the disease (indicated by arrows). (B) PPV symptoms (indicated by arrows) in the Nemaguard peach grafted onto GF305 also showing symptoms of the disease.
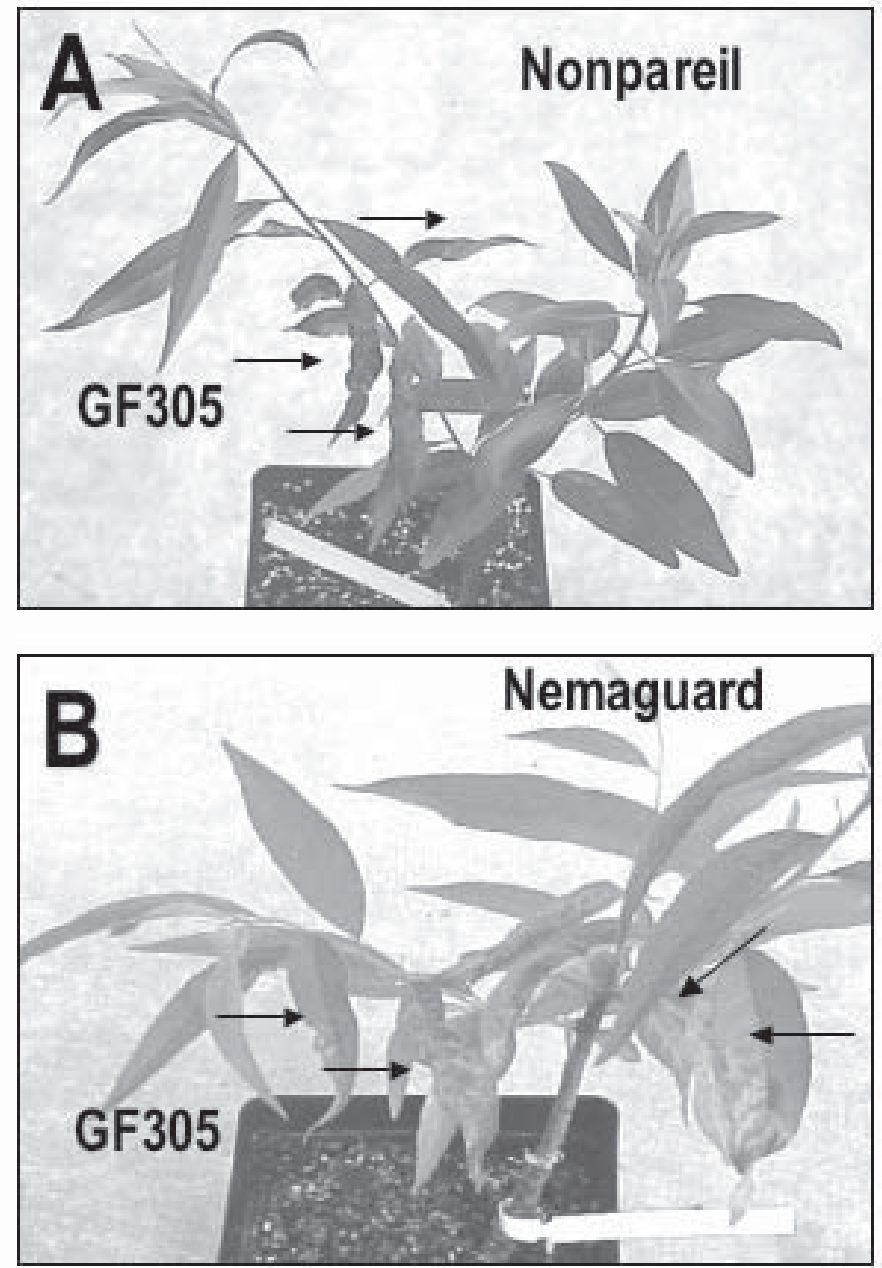
al. (1986), samples with OD at least double those of the healthy control were considered ELISA-positive.

RT-PCR ANALYSIS. RT-PCR analysis (Wetzel et al., 1991) was carried out using total RNA extracted using the Rneasy Plant Mini Kit (Quiagen, Valencia, Calif.) as described by MacKenzie et al. (1997). Two specific primers within the coat protein(CP) gene, VP337 (CTCTGTGTCCTCTTCTTGTG) complementary to 9487-9508 positions of genomic PPV and VP338 (CAATAAAGCCATTGTTGGATC) homologous to 9194 to 9216 positions, were assayed. PCR parameters were: one cycle at $94^{\circ} \mathrm{C}$ for $2 \mathrm{~min}$ followed by 30 cycles of $94^{\circ} \mathrm{C}$ for $30 \mathrm{~s}, 55^{\circ} \mathrm{C}$ for $30 \mathrm{~s}$ and $72{ }^{\circ} \mathrm{C}$ for $30 \mathrm{~s}$, and finally with an extension temperature at $72^{\circ} \mathrm{C}$ for $5 \mathrm{~min}$ (Martínez-Gómez et al., 2003a).Amplified products were electrophoresed in 1\% agarose gels in $40 \mathrm{~mm}$ Tris-acetate and $1 \mathrm{~mm}$ EDTA, pH 8.0 (TAE) and stained with ethidium bromide. A 1-kb plus DNA Ladder (Invitrogen Life Technologies) was used as molecular size standard.

\section{Results}

All almond cultivars grafted onto previously inoculated GF305 peach rootstocks showed resistance to the PPV-D isolate assayed after three cycles of study (Table 2). They did not show any symptoms and were ELISA-DASI and RT-PCR negative (Fig. 2) despite the symptoms observed in the GF305 rootstock .

Processing peach cultivars Andross, Bolinha, Dr. Davis, Halford, and Ross, peach breeding parent ' $54 \mathrm{P} 455$ ', and the peach rootstocks Lovell and Nemaguard, were susceptible to the PPV-D isolate assayed. Symptomatic plants developed chlorotic discoloration and distortion of leaves characteristic of PPV (Fig. 1) and assayed positive by ELISA-DASI or RT-PCR during at least one of the three growth cycles assayed (Table 2).

Interspecific almond $x$ peach hybrids, including the 'Hansen 536' and 'Nickels' rootstocks, and the ('Padre' $\mathrm{x}$ '54P455' peach) hybrid '7926-1', demonstrated resistance. Six of the eight almond $x$ peach derived genotypes also showed a resistant response to the PPV-D isolate assayed. Peach-type selection 'F8,5-156' and almond breeding selections 'F10C,12-28', and'F10C,20-51', showed a resistant behavior toward PPV (Table 2, Fig. 2). Plants appeared normal for three growth cycles and tested negative by ELISA-DASI and RT-PCR. Peach breeding lines '99,15-154' and 'F8,5166' developed PPV symptoms.

Symptomatic plants were always associated with high ELISADASI OD values (Table 2). Four of the symptomatic and ELISADASI positive genotypes also gave positive RT-PCR responses while three other symptomatic ELISA-DASI positive genotypes gave negative RT-PCR responses.

Table 2. Evaluation of resistance of genotype assayed to plum pox virus (PPV)-D isolate RB3.30 of PPV.

\begin{tabular}{|c|c|c|c|c|c|c|c|c|c|c|c|c|}
\hline \multirow[b]{4}{*}{ Genotype } & \multirow[b]{4}{*}{$\begin{array}{c}\text { Plants } \\
\text { evaluated }\end{array}$} & \multicolumn{4}{|c|}{ Cycle 1} & \multirow{2}{*}{\multicolumn{2}{|c|}{$\begin{array}{c}\text { Cycle } 2 \\
\text { Symptoms }\end{array}$}} & \multicolumn{5}{|c|}{ Cycle 3} \\
\hline & & \multicolumn{2}{|c|}{ Symptoms } & \multirow{2}{*}{\multicolumn{2}{|c|}{ ELISA-DASI }} & & & \multicolumn{2}{|c|}{ Symptoms } & \multirow{2}{*}{\multicolumn{2}{|c|}{ ELISA-DASI }} & \multirow[b]{3}{*}{ RT-PCR z } \\
\hline & & \multirow[b]{2}{*}{$\begin{array}{c}\text { Symptomatic } \\
\text { plants }\end{array}$} & \multirow{2}{*}{$\begin{array}{c}\text { Mean } \\
\text { intensity } \\
\text { of } \\
\text { symptoms } \\
\end{array}$} & & & & $\begin{array}{c}\text { Mean } \\
\text { intensity }\end{array}$ & & $\begin{array}{c}\text { Mean } \\
\text { intensity }\end{array}$ & & & \\
\hline & & & & $\begin{array}{c}\text { Positive } \\
\text { plants } \\
\end{array}$ & $\mathrm{OD}_{405^{y}}^{\mathrm{y}}$ & $\begin{array}{c}\text { Symptomatic } \\
\text { plants }\end{array}$ & $\begin{array}{c}\text { of } \\
\text { symptoms } \\
\end{array}$ & $\begin{array}{c}\text { Symptomatic } \\
\text { plants }\end{array}$ & $\begin{array}{c}\text { of } \\
\text { symptoms }\end{array}$ & $\begin{array}{c}\text { Positive } \\
\text { plants }\end{array}$ & $\mathrm{OD}_{405}$ & \\
\hline \multicolumn{13}{|l|}{ Almond } \\
\hline Carmel & 3 & 0 & 0 & 0 & 0.06 & 0 & 0 & 0 & 0 & 0 & 0.06 & - \\
\hline Mission & 4 & 0 & 0 & 0 & 0.10 & 0 & 0 & 0 & 0 & 0 & 0.06 & - \\
\hline NePlusUltra & 1 & 0 & 0 & 0 & 0.07 & 0 & 0 & 0 & 0 & 0 & 0.06 & - \\
\hline Nonpareil & 3 & 0 & 0 & 0 & 0.10 & 0 & 0 & 0 & 0 & 0 & 0.06 & - \\
\hline Padre & 2 & 0 & 0 & 0 & 0.09 & 0 & 0 & 0 & 0 & 0 & 0.06 & - \\
\hline Price & 1 & 0 & 0 & 0 & 0.08 & --- & --- & --- & --- & --- & --- & --- \\
\hline Sonora & 1 & 0 & 0 & 0 & 0.10 & 0 & 0 & 0 & 0 & 0 & 0.05 & - \\
\hline \multicolumn{13}{|l|}{ Peach } \\
\hline Andross & 4 & 0 & 0 & 0 & 0.11 & 0 & 0 & 1 & 1.0 & 1 & 0.35 & + \\
\hline Bolinha & 3 & 1 & 1.0 & 1 & 0.40 & 0 & 0 & 0 & 0 & 0 & 0.06 & - \\
\hline Dr. Davis & 5 & 2 & 1.0 & 2 & 0.63 & 0 & 0 & 1 & 1.0 & 1 & 0.20 & - \\
\hline Halford & 3 & 1 & 1.0 & 1 & 0.59 & 0 & 0 & 1 & 1.0 & 1 & 0.18 & + \\
\hline Ross & 4 & 0 & 0 & 0 & 0.09 & 1 & 1.0 & 1 & 1.0 & 1 & 0.18 & - \\
\hline \multicolumn{13}{|l|}{ Peach rootstock } \\
\hline Lovell & 3 & 1 & 2.0 & 1 & 1.14 & 0 & 0 & 0 & 0 & 0 & 0.06 & - \\
\hline Nemaguard & 2 & 2 & 2.0 & 2 & 1.89 & 0 & 0 & 1 & 1.0 & 1 & 0.20 & - \\
\hline \multicolumn{13}{|l|}{ Hybrid rootstock } \\
\hline Hansen 536 & 3 & 0 & 0 & 0 & 0.06 & 0 & 0 & 0 & 0 & 0 & 0.06 & - \\
\hline Nickels & 3 & 0 & 0 & 0 & 0.06 & 0 & 0 & 0 & 0 & 0 & 0.06 & - \\
\hline \multicolumn{13}{|l|}{ Breeding lines } \\
\hline $54 \mathrm{P} 455$ & 5 & 3 & 1.5 & 3 & 0.71 & 0 & 0 & 3 & 1.5 & 3 & 0.46 & + \\
\hline $7926-1$ & 1 & 0 & 0 & 0 & 0.07 & 0 & 0 & 0 & 0 & 0 & 0.07 & - \\
\hline F10C,20-51 & 3 & 0 & 0 & 0 & 0.08 & 0 & 0 & 0 & 0 & 0 & 0.06 & - \\
\hline $\mathrm{F} 10 \mathrm{C}, 12-28$ & 4 & 0 & 0 & 0 & 0.08 & 0 & 0 & 0 & 0 & 0 & 0.06 & - \\
\hline F8,5-156 & 2 & 0 & 0 & 0 & 0.06 & 0 & 0 & 0 & 0 & 0 & 0.06 & - \\
\hline F8,5-166 & 5 & 0 & 0 & 0 & 0.10 & 1 & 2.0 & 0 & 0 & 0 & 0.05 & - \\
\hline $99,15-154$ & 3 & 1 & 2.0 & 1 & 1.68 & 0 & 0 & 1 & 1.0 & 1 & 0.27 & + \\
\hline
\end{tabular}

${ }^{2}$ Positive (+) or negative $(-)$ reaction.

$\mathrm{yOD}_{405}=$ optical density at $405 \mathrm{~nm}$ values after $60 \mathrm{~min}$. Mean $\mathrm{OD}_{405}$ in infected and healthy GF305 peach rootstocks were 1.80 and 0.07 , respectively.

xIntensity: $0=$ no symptoms to $5=$ maximum intensity of leaf chlorosis and distortion. Mean intensity of PPV symptoms in infected GF305 peach rootstocks was 3.0 . 


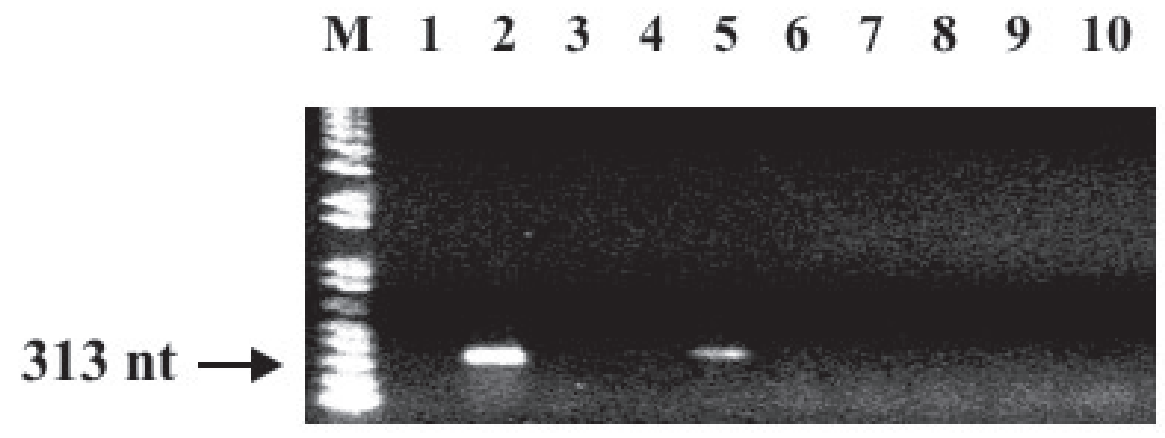

Fig. 2. Amplification products (313 bp) indicative of the presence of plum pox virus (PPV) obtained using RT-PCR for PPV detection in different samples. Lane 1 = healthy GF305 rootstock, lane 2 = GF305 rootstock infected by PPV and showing strong sharka symptoms, lane 3 = 'Hansen 536', lane 4 = 'Nonpareil', lane $5=$ '54,P455' peach, lane $6=$ 'Mission', lane $7=$ 'Ne Plus Ultra', lane $8=$ 'F10C,12-28', lane $9=$ 'F10C,20-51', and lane $10=$ 'F8,5-156'. Lane M = molecular weight marker $1 \mathrm{~kb}$ plus DNA ladder.

\section{Discussion}

Results demonstrate the susceptibility of the peach cultivars and peach rootstocks assayed. These findings agree with previous studies reporting the absence of resistance to PPV in peach (Escalettes et al., 1998; Gabova, 1994; Pascal et al., 2003). While Escalettes et al. (1998) have suggested resistance in some ornamental peach selections, the possible interspecies origin of these selections was not ruled out.

Susceptibility was observed in the 'Nemaguard' seedling rootstock, a probable progeny of a cross between peach and Prunus davidiana (Carr.) Franch. (Martínez-Gómez et al., 2003b). Pascal et al. (2003) reported resistance in several $P$. davidiana lines to a PPV-M isolate which was different from the PPV-D isolate used in this study.

Mean intensity of PPV symptoms of all the infected peach genotypes was of 1.4. This intensity is very low in comparison to the mean intensity of $\approx 3.0$ observed in the infected GF305 rootstock, confirming the high susceptibility described for this rootstock (Bernhard et al., 1969). In addition, the intensity of symptoms is lower than the mean values of $\approx 2.0$ observed in a previous evaluation of apricot cultivars with this PPV-D isolate, (Martínez-Gómez and Dicenta 2000). These results confirm the lower level of susceptibility of peach to PPV-D isolates in comparison to apricot (Kölber, 2001; Quiot et al., 1995), with the notable exception of the GF305 peach rootstock.

The very irregular distribution and the low concentration of PPV described in Prunus tissues (Albrechtova, 1986; Audergon et al., 1989) would result in an irregular manifestation of PPV symptoms as observed in the replications of each cultivar during the three studied cycles. In many cases, some of the inoculated replications of a given cultivar showed PPV symptoms while others did not. This irregular distribution has important implications for virus detection, since it means that plants which are really infected may appear healthy (Marenaud and Yürektürk, 1974; Desvignes, 1976, Quiot et al., 1995). In this evaluation, we considered that genotypes were susceptible to PPV that showed PPV symptoms or were positive by ELISA-DASI or RT-PCR during any of the growth cycles assayed. This more conservative screening strategy has given consistent results in previously reported disease studies (Dicenta et al., 2003; Martínez-Gómez and Dicenta, 1999, 2000; MartínezGómez et al., 2003a). In our assays, the first and the third cycles of study were performed during the spring, whereas the second cycle of study was performed at the end of summer when temperatures were higher. Hubert et al. (1988) observed that high temperatures reduce the manifestation of PPV symptoms in Prunus. Higher temperatures, thus, may have contributed to the lower PPV symptoms observed during the second cycle of the study.

All plants showing symptoms also gave positive ELISA-DASI readings. In addition, detection of PPV by RT-PCR during the third cycle confirmed the results obtained by ELISADASI.All samples that were positive by RT-PCR were also positive by ELISA-DASI. However, in the cases of lower OD of ELISA-DASI (peach cultivars Dr. Davis and Ross, and Nemaguard rootstock), the RT-PCR was negative. While a higher sensitivity has been reported for the RT-PCR in comparison to the ELISA-DASI (Candresse et al., 1994; Martínez-Gómez et al., 2003a; Wetzel et al., 1991), the erratic distribution of PPV common in infected Prunus tissue together with the presence of PCR inhibitors described by Olmos et al. (2002) in some Prunus tissues could have contributed to false RT-PCR negatives.

The level of resistance to the PPV-D isolate of all the California almond cultivars assayed support Dicenta et al. (2003), Pascal et al. (2003), and Rubio et al. (2003), who reported the resistance of selected European almond cultivars to PPV-D and PPV-M isolates. Dallot et al. (1997), detected the PPV virus by ELISA in 'Aï' almond cultivar, after graft-inoculation with five Dideron, three Marcus, and one El Amar isolates. However, the ODs they obtained were low, particularly in the almond inoculated with PPV-D isolates. Only one isolate induced some chlorotic discoloration of the leaves of 'Aï', which rapidly disappeared. Dallot et al. (1997) also demonstrated a lower rate of infection by PPV-D isolates, as described previously by Quiot et al. (1995) in apricot and peach. While 'Aï', may represent a particular case of susceptibility among almond cultivars, Dallot et al. (1997) did not find any ELISA-positive samples after analyzing 356 trees in a field survey.

Results support the low potential of the almond genotypes used in this study as virus sources in sharka epidemics where Type D isolates of PPV are involved. The almond cultivars used in this study represent $\approx 70 \%$ of current production in California, with most remaining commercial varieties being the progeny of crosses between the resistant 'Nonpareil' and 'Mission' varieties (Martínez-Gómez et al., 2003b). Type D, which is the most readily transmitted isolate, is the major isolate found in Western Europe and the only isolate reported in North and South America (Damsteegt et al., 2001). In both Western Europe and North America, the control of PPV is through widespread and recurrent visual and ELISA-DASI based surveys of existing orchards with tree removal and quarantine restrictions when PPV is found. Confirmation of a freedom from PPV in remaining almond cultivars planted in California could lead to the exclusion of these almond varieties as a potential virus reservoir. In California, where plantings of these almond varieties account for $\approx 180,000$ ha, their removal as a potential host species would allow a more efficient focusing of virus surveys to susceptible Prunus crops.

These findings support the hypothesis that transfer of some level of PPV resistance from almond to peach breeding lines is possible. All almond $\mathrm{x}$ peach hybrids as well as six of the eight genotypes derived from interspecific hybridizations were resistant to PPV. The absence of any formidable crossing barriers in either 
the initial hybridization or subsequent backcrosses between peach and almond (Gradziel et al., 2001; Gradziel, 2003) further supports the suitability of almond germplasm for peach improvement. Two resistant breeding lines, 'F10C,20-51' and 'F10C,12-28', have an almond-type tree and nut, and were selected for their high level of self-compatibility derived from the peach parent. The resistant selection 'F8,5-156' and the susceptible selection 'F8,5-166' have a peach-type tree and fruit and were selected for good canning quality and uniform fruit ripening within the tree. All selections resulted from interspecific hybridization between the resistant 'Padre' almond and the susceptible '54P455' peach. The quarantine safeguards required for PPV testing limited the number of peach and almond selections for this initial evaluation. The selections '54P455' peach, '7926-1' interspecific hybrid, and derived progeny were selected for testing since this was the population used for developing the genetic map for peach and almond (Bliss et al., 2002; Foolad et al., 1995) and our eventual goal is to map the resistance gene(s) in almond. The lack of native sources of resistance within peach (Dosba et al., 1994; Escalettes et al., 1998; Gabova, 1994; Pascal et al., 2003) also make almond species a valuable source of PPV resistance for peach species, as previously proposed by Gradziel (2003) and Pascal et al. (2003). Pascal et al. (2003) have reported resistance to PPV Type $\mathrm{M}$ in several $P$. davidiana lines, but Moing et al. (2003) had indicated that poor fruit quality is transmitted from $P$. davidiana to peach, which was not a problem in advanced almond-derived peach selections (Gradziel, 2003).

\section{Literature Cited}

Albrechtova, L. 1986. Investigations on the distribution of sharka virus (plum pox) in tissue of Prunus domestica. Z. Pflanz. Pflanz. 93:190-201.

Asensio, M. 1996. El virus de la sharka (plum pox virus). Caracterización, diagnóstico y detección mediante anticuerpos monoclonales específicos. $\mathrm{PhD}$ diss., Univ. Valencia, Spain.

Audergon, J.M., F. Dosba, I. Karayiannis, and F. Dicenta. 1994. Amélioration de l'abricotier pour la résistance à la sharka. EPPO Bul. 24:741-748.

Audergon, J.M., P. Monestiez, G. Labonne, and J.B. Quiot. 1989. Virus de la sharka. Répartition spatiale du virus dans un arbre. Abstracts, $2^{e}$ Rencontres de Virologie Végétale, Jan. 1989, Aussois, France. 13.

Bernhard, R., C. Marénaud, and D. Sutic. 1969. Le pêcher GF305 indicateur polyvalent des virus des espèces a noyau. Ann. Phytopathol. 1:603-617.

Bliss, F.A., S. Arulsekar, M.S.R. Foolad, V. Becerra, C.E. Thormann, A.M. Gillen, M.L. Warburton, A.M. Dandekar, G.M. Kocsisne, S. Pace, and E.W. Myers. 2002. An expanded genetic linkage map of Prunus based on an interspecific cross between almond and peach. Genome 45:520-529.

Cambra, M., M. Asensio, M.T. Gorris, J.A. García, J.J. Moya, D. LópezAbella, C. Vela, and A. Sanz. 1994. Detection of plum pox potyvirus using monoclonal antibodies to structural and nonstructural proteins. EPPO Bul. 24:569-578.

Candresse, T., G. MacQuaire, M. Lanneau, M. Bousalem, T. Wetzel, L. QuiotDouine, J.B. Quiot, and J. Dunez. 1994. Detection of Plum pox potyvirus and analysis of its molecular variability using immunocapture-PCR. EPPO Bul. 24:585-595.

Crescenzi, A., L. d’Aquino, S. Comes, M. Nuzzaci, and P. Piazzola. 1997. Characterization of sweet cherry isolate of plum pox potyvirus. Plant Dis. 81:711-714.

Dallot, S., M. Bousalem, M. Boeglin, L.Y. Renaud, and J.B. Quiot. 1997. Potential role of almond in sharka epidemics: susceptibility under controlled conditions to the main types of plum pox potyvirus and survey for natural infections in France. EPPO Bul. 27:539-546.

Damsteegt, V.S.,A.L. Stone, D.G. Luster, F.E. Gildow, L. Levy, and R. Welliver. 2001. Preliminary characterization of a North American isolate of plum pox virus from naturally infected peach and plum orchards in Pennsylvania. Acta Hort. 550:145-151.

Desvignes, J.C. 1976. The virus diseases detected in greenhouse and in field by the peach seedling GF305 indicator. Acta Hort. 67:47-48.

Dicenta, F., M. Rubio, M. Gambin, and P. Martínez-Gómez. 2003. Resistance of almond cultivars to sharka (plum pox virus). Acta Hort. 591:577-579.
Dosba, F., M. Lansac, J.P. Eyquard. 1994. Résistance des Prunus a la sharka. EPPO Bul. 24:691-696.

Egea J., L. Burgos, P. Martínez-Gómez, and F. Dicenta. 1999. Apricot breeding for sharka resistance at CEBAS-CSIC, Murcia (Spain). Acta Hort. 488: 153-157.

Escalettes, V., F. Dosba, M. Lansac, J.P. Eyquard, and R. Monet. 1998. Genetic resistance to PPV in peaches. Acta Hort. 465:689-697.

Foolad, M.S.R., S. Arulsekar, V. Becerra, and F.A. Bliss. 1995. A genetic map of Prunus based on an interspecific cross between almond and peach. Theor. Appl. Genet. 91:262-269.

Gabova, M. 1994. Evaluation of peach and nectarine cultivars in Bulgaria for their resistance to plum pox potyvirus. EPPO Bul. 24:755-760.

Gradziel, T.M. 2003. Almond species as source of new genes for peach improvement. Acta Hort. 592:81-88.

Gradziel, T.M., P. Martínez-Gómez, F. Dicenta, and D.E. Kester. 2001. The utilization of related almond species for almond variety improvement. J. Amer. Pomol. Soc. 55:100-109.

Hubert, I., B. Parqueteau, and G. Pecheur. 1988. La lutte contre la sharka en France. L'action du service de la protection des vegetaux. Bul. Tech. Info. $1: 465-480$.

Kegler M., M. Grüntzig, and E. Fuchs, 1994. A glasshouse test detecting resistance of plum genotypes to plum pox virus. Acta Hort. 359:152-158.

Kölber, M. 2001. Workshop on plum pox. Acta Hort. 550:249-255.

Levy, L., V.S. Damsteegt, and R. Welliver. 2000. First report of plum pox virus (sharka disease) in Prunus persica in the United States. Plant Dis. 84:202.

MacKenzie, D.J., M.A. McLean, S. Mukerji, and M. Green. 1997. Improved RNA extraction from woody plants for the detection of viral pathogens by reverse transcription-polymerase chain reaction. Plant Dis. 81:222.

Marenaud, C. and M. Yürektürk. 1974. Problèmes posés par la détection du virus de la sharka. Pomologie Française 16:207-214.

Martínez-Gómez, P. and F. Dicenta. 1999. Evaluation of resistance to sharka in the breeding apricot program in CEBAS-CSIC in Murcia (Spain). Acta Hort. 488:731-737.

Martínez-Gómez, P. and F. Dicenta. 2000. Evaluation of resistance of apricot cultivars to a Spanish isolated of plum pox virus. Plant Breed. 119: 179-181.

Martínez-Gómez, P., M. Rubio, F. Dicenta, F. Aparicio, and V. Pallás. 2003a. Comparative analysis of three diagnostic methods for the evaluation of Plum pox virus (PPV) resistance in apricot breeding programs. XXVI Intl. Hort. Congr. Toronto, Canada. 335. Acta Hort. 622:353-357.

Martínez-Gómez, P., S. Arulsekar, D. Potter, and T.M. Gradziel. 2003b. An extended interspecific gene pool available to peach and almond breeding as characterized using simple sequence repeat (SSR) markers. Euphytica 131:313-322.

Moing A., J.L. Poëssel, L. Svanella-Dumas, M. Loonis, and J. Kervella. 2003. Biochemical basis of low fruit quality of Prunus davidiana, a pest and disease resistance donor for peach breeding. J. Amer. Soc. Hort. Sci. 128:55-62.

Németh, M. 1994. History and importance of plum pox in stone-fruit production. EPPO Bul. 24:525-537.

Olmos, A., E. Bertolini, and M. Cambra. 2002. Simultaneous and co-operational amplification (Co-PCR): A new concept for detection of plant viruses. J. Virol. Meth. 106:51-59.

Pascal, T., F. Pfeiffer, and J. Kervella. 2003. Preliminary observations on the resistance to sharka in peach and related species. Acta Hort. 592:699-704.

Pribék, D., R. Gáborjányi, and L. Palkovics. 2001. Molecular characterization of plum pox virus almond isolate. Acta Hort. 550:91-95.

Quiot, J.B., G. Labonne, M. Boeglin, C. Adamolle, L.Y. Renaud, and T. Candresse. 1995. Behavior of two isolates of plum pox inoculated on peach and apricot trees. First results. Acta Hort. 386:290-297.

Reyes, F., M.A. Reyes, P. Sepúlveda, J.J. López-Moya, and H. Prieto. 2001. New insights of plum pox virus in Chile. Acta Hort. 550:135-140.

Rubio, M., P. Martínez-Gómez, and F. Dicenta. 2003. Resistance of almond cultivars to plum pox virus (sharka). Plant Breed. 122:462-464.

Sutula, C.L., J.M. Gillet, S.M. Morrissey, and D.C. Ramsdell. 1986. Interpreting ELISA data and establishing the positive-negative threshold. Plant Dis. 70:722-726

Watkins, R. 1976. Cherry, plum, peach, apricot and almond. In: N.W. Simmonds (ed.). Evolution of crop plants. Longman, London.

Wetzel, T., T. Candresse, M. Ravelonandro, and J. Dunez. 1991. A polymerase chain reaction assay adapted to plum pox potyvirus detection. J. Virol. Meth. 33:355-365. 